K. Nebti, R. Lebied

\title{
FUZZY MAXIMUM POWER POINT TRACKING COMPARED TO SLIDING MODE TECHNIQUE FOR PHOTOVOLTAIC SYSTEMS BASED ON DC-DC BOOST CONVERTER
}

\begin{abstract}
Aim. This paper presents the amelioration of maximum power point tracking using fuzzy logic methods for photovoltaic system supplying a standalone system. Method. The main role of the maximum power tracking is to force the system for working at the maximum point for each change of meteorological conditions. The classic technique Perturb and Observe is more attractive due to its simple and high efficiency. Sliding mode is a non-linear control technique; characterised by robustness against the parameters change or disturbances, it gives a good maximum power operation under different conditions such as changing solar radiation and photovoltaic cell temperature. Novelty. Fuzzy logic tracking technique is treated. Fuzzy rules construction is based on Perturb and Observe behaviour when the appropriate disturbance step is produced in order to obtain a fast system with an acceptable precision. We use in our study $60 \mathrm{~W}$ photovoltaic panel associated to boost chopper converter in order to supply a standalone system. Results. As show in results figures using fuzzy maximum power point tracking the ameliorate performances especially the very low oscillation rate (nearly $0.6 \mathrm{~W}$ ), and very acceptable response time $0.1 \mathrm{~s}$. References 20 , tables 1 , figures 19.
\end{abstract}

Key words: solar panel, maximum power point tracking, perturb and observe, sliding mode, Fuzzy logic.

\begin{abstract}
Мета. У иій роботі представлено покращення відстеження точки максимальної потужності з використанням методів нечіткої логіки для фотоелектричної системи, щзо постачає електроенергію до автономної системи. Метод. Основна роль відстеження максимальної потужності - примусити систему працювати в максимальній точиі при кожній зміні метеорологічних умов. Класична техніка збурення та спостереження є більш привабливою завдяки своїй простоті та високій ефективності. Режим ковзання - ие нелінійний метод керування; характеризується стійкістю до зміни параметрів або порушень, дає хорошу максимальну потужність роботи в різних умовах, таких як зміна сонячного випромінювання та температури фотоелектричних елементів. Новизна. Використовується методика відстеження з використанням нечіткої логіки. Побудова нечітких правил базується на поведінці збурення та спостереження, коли виробляється відповідний крок збурення, щоб отримати швидку систему з прийнятною точністю. У иьому дослідженні використовується фотоелектрична панель потужністю 60 Вт, підключена до перетворювача, щъо підвищує, для постачання електроенергії до автономної системи. Результати. Як показують результати, дані використовують нечітку максимальну точку потужності, яка відстежує покращені характеристики, особливо дуже низьку швидкість коливань (майже 0,6 Вт) i дуже прийнятний час відгуку 0,1 с. Бібл. 20, табл. 1, рис. 19.
\end{abstract}

Ключові слова: сонячна панель, відстеження точки максимальної потужності, збурення та спостереження, режим ковзання, нечітка логіка.

Introduction. Renewable energies represent an attractive solution as replacement or complement of the conventional sources. Among renewable energies, are those resulting from the sun, wind, heat of the ground, water or of the biomass. With the difference in fossil energies, renewable energies are unlimited resource. Renewable energies are divided in a certain number of technological fields according to the developed energy source and useful energy obtained. The field studied in this paper is photovoltaic (PV) solar.

In direct couplings of the loads to PV system, the PV panels are often oversized to ensure a sufficient power to provide the load; this led to an excessively expensive system.

It very is easy to calculate the operating power of the PV panels. But, the determination of the reference power is more delicate view that it is function of meteorological parameters (temperature and illumination).

This variable reference, characterized by a non-linear function, makes the operation at maximum power more difficult to achieve. Then, maximum power point tracking (MPPT) is necessary. Generally it is based on the adjustment of the duty cycle controlling the static converter until it is placed on the PPM. Different MPPT methods have been published in the literature for optimal functioning, such as short-circuit current, incremental conductance algorithms, modified hill climbing MPPT method [1].
Perturb and observe (P\&O) method is largely widespread approach in the research of the MPPT because it is simple and requires only measurements of voltage and current of the photovoltaic panel $\left(V_{P V}\right.$ and $I_{P V}$ respectively, two sensors necessary), it should be known that this type of control imposes a permanent oscillation around the maximum power point (MPP) [2].

The sliding mode control technique is generally used to control the power electronics converters that constitute systems with variable structure [3, 4]. Recently sliding mode is used to control a grid connected PV system $[5,6]$ supplying stand alone PV system such as the pumping system.

In order to ameliorate the respond time and eliminate the oscillation around the MPP, a fuzzy control based on P\&O idea is applied with different membership and fuzzy rules at both sides of MPP. Under this method, the perturbation step is adjusted according to controller inputs and working point.

The aim of this paper is the amelioration of maximum power point tracking using fuzzy logic methods for photovoltaic system supplying a standalone system.

Electric model of PV cell. To predict the PV system performance, it is better to make an equivalent model and analyze its behavior under variable conditions. 
The simplified equivalent circuit of the PV cell with junction $p$ - $n$ (Fig. 1) includes a current source $I_{P V}$, who gives the photoelectric current model, associated with a diode in parallel which gives the junction $p-n$ model, whose polarization determines voltage.

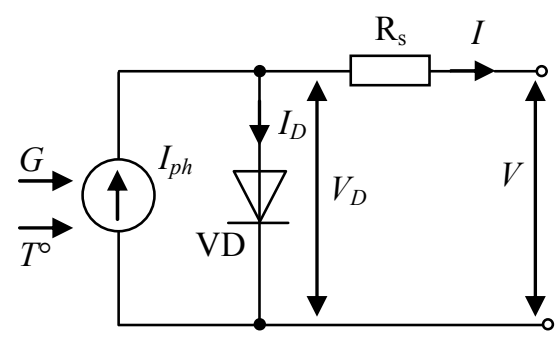

Fig. 1. Equivalent model of the simplified PV cell

And also a series resistance which is the internal resistance of the cell, it depends mainly on the resistance of the semiconductor used, it is also affected by temperature influence [7]

$$
\begin{gathered}
I=I_{p h}+I_{D} ; \\
I_{p h}=I_{p h}\left(T_{1}\right) \cdot\left[1+K_{0} \cdot\left(T-T_{1}\right)\right] ; \\
I_{p h}\left(T_{1}\right)=I_{c c}\left(T_{1}\right) \cdot\left(\frac{G}{G_{0}}\right),
\end{gathered}
$$

where $I$ is the current produced by the PV cell; $I_{p h}$ is the photonic current, proportional to the illumination $G ; I_{D}$ is the current flowing through the diode; $T_{1}$ is the reference temperature $\left(T_{1}=25{ }^{\circ} \mathrm{C}=298{ }^{\circ} \mathrm{K}\right) ; G_{0}$ is the reference illumination $\left(G_{0}=1000 \mathrm{~W} / \mathrm{m}^{2}\right) ; K_{0}$ is the coefficient of variation of the current as a function of the temperature $T$; $I_{c c}$ is the short-circuit current (the current flowing through the junction under illumination when the cell is shortcircuited).

And the relationship between current and voltage of a solar cell is:

$$
I=I_{p h}-I_{s}\left(e^{\left(\frac{q\left(V+R_{s} \cdot I\right)}{n k_{b} T}\right)}-1\right),
$$

where $I_{s}$ is the saturation current; $k_{b}$ is Boltzmann constant; $V$ is the voltage at the cell terminals; $R_{S}$ is the resistance series; $n$ is the diode ideality factor, where $1<n<2 ; q$ is the electron charge $\left(q=1.602 \cdot 10^{-19} \mathrm{C}\right)$.

Boost converter modeling. Boost converter (Fig. 2) is composed of a boost inductance $\mathrm{L}$, a controlled switch $\mathrm{K}$, a diode $\mathrm{VD}$ and filtering capacitors $\mathrm{C}$. When the switch $\mathrm{K}$ is on, the boost inductance current increases linearly, the diode VD being blocked. When switch $\mathrm{K}$ is off, the energy stored in the inductor, pass through the diode to the output circuit [8].

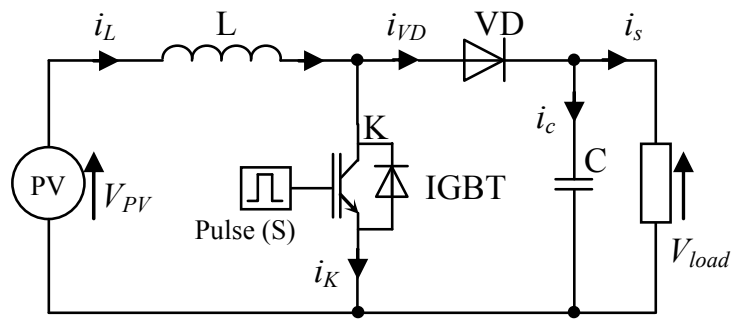

Fig. 2. DC-DC boost chopper scheme
The modeling of this converter passes by the analysis of the different operation sequences that we will suppose durations fixed by the command $\mathrm{S}$. There appear two operation sequences according to the state of the switch K.

When $\mathrm{K}$ is closed so VD is opened:

$$
\begin{aligned}
& V_{P V}=L \frac{d i_{L}}{d t} ; \\
& 0=C \frac{d V_{\text {load }}}{d t}+i_{s} .
\end{aligned}
$$

When $\mathrm{K}$ is opened:

$$
\begin{aligned}
& V_{P V}=L \frac{d i_{L}}{d t}+V_{\text {load }} ; \\
& i_{L}=C \frac{d V_{\text {load }}}{d t}+i_{S} .
\end{aligned}
$$

By putting $(\mathrm{S}=1)$ when the switch $\mathrm{K}$ is closed and $(\mathrm{S}=0)$ for open $\mathrm{K}$, we can represent the converter according to the switch state $\mathrm{S}$ by the following equations:

$$
\begin{gathered}
V_{P V}=L \frac{d i_{L}}{d t}+V_{\text {load }} \cdot(1-S) \\
(1-S) \cdot i_{L}=C \frac{d V_{\text {load }}}{d t}+i_{s} .
\end{gathered}
$$

Perturb and observe algorithm. The principle of P\&O MPPT control is to disturb the voltage $V_{P V}$ with a low amplitude around its initial value and analyze the behaviour of the power variation $P_{P V}$ resulting. So, as shown in Fig. 3, we can deduce if a positive increment of the voltage $V_{P V}$ generates increased power $P_{P V}$ that means that the operating point is left of MPP. If not the system has exceeded the MPP. Similar reasoning can be made when the voltage decreases $[9,10]$.

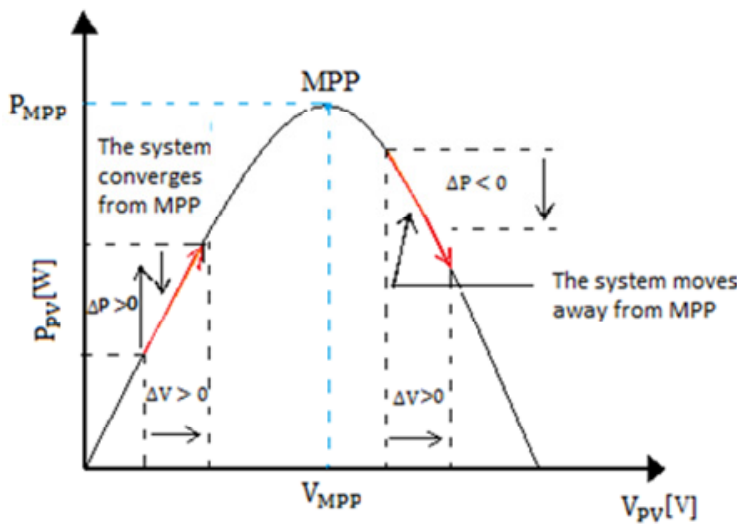

Fig. 3. P\&O principle

At each cycle, $V_{P V}$ and $I_{P V}$ are measured to calculate $P_{P V}(k)$, where $k$ indicate the present cycle. This value $P_{P V}(k)$ is compared with the value $P_{P V}(k-1)$ calculated in the previous cycle.

The disadvantage of this type of control is that if quick change of the illumination such as a mobile cloud, this command has more losses, generated by the long response time of the control to reach the new MPP.

P\&O MPPT simulation. We apply two fast change of illumination, the first at time $t=0.4 \mathrm{~s}$, from $1000 \mathrm{~W} / \mathrm{m}^{2}$ to $700 \mathrm{~W} / \mathrm{m}^{2}$ and the second at time $t=0.8 \mathrm{~s}$ from $700 \mathrm{~W} / \mathrm{m}^{2}$ to $900 \mathrm{~W} / \mathrm{m}^{2}$. 
In Fig.4-6 which represent the evolution of the current, power and voltage, these curves contain fluctuations, especially in transient periods, due to the oscillation of P\&O around MPP with fixed step.

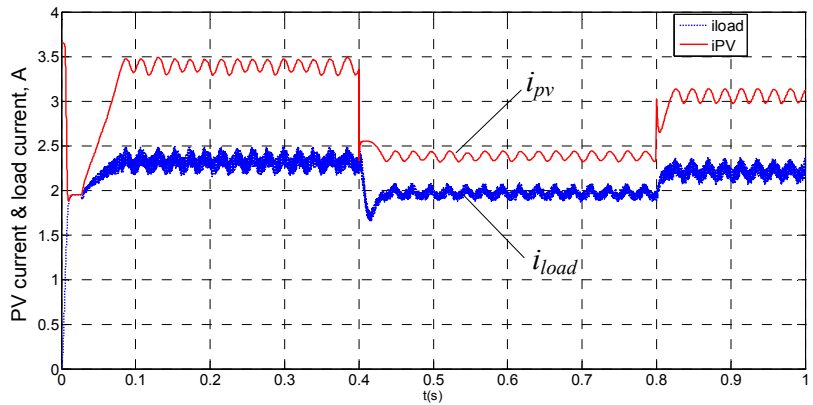

Fig. 4. Load and PV panel current for P\&O MPPT

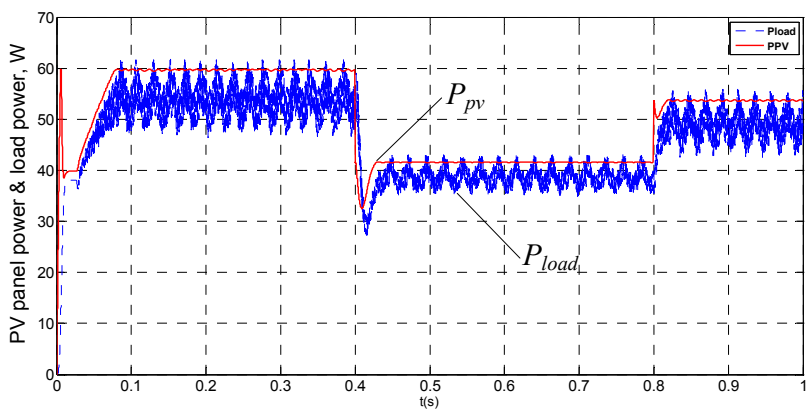

Fig. 5. Load and PV panel power for P\&O MPPT

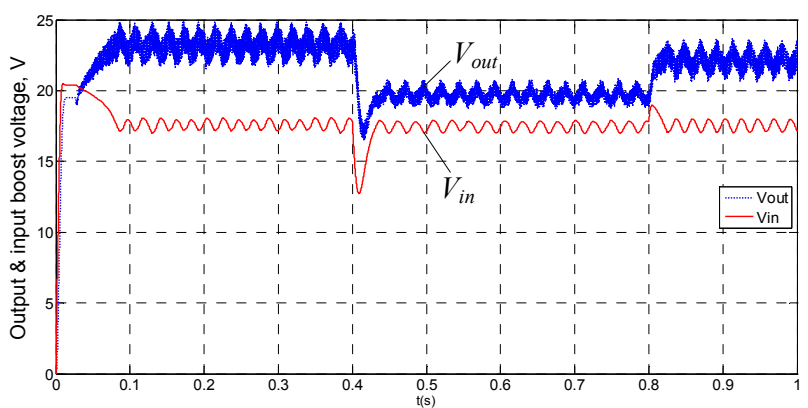

Fig. 6. Load and PV panel voltage for P\&O MPPT

But in other side we observe that the output power follow the power generated by the PV panel, we keep the operating point on the MPP, which confirm the effectiveness of this method. The difference in power is due to the converter losses.

$\mathrm{P} \& \mathrm{O}$ technique is based on applying a disturbance to the voltage (positive or negative) to reach the maximum power point.

The problem with this technique is that the disturbance is fixed. In order to reach the point max quickly, we must apply a large disturbance, but this causes ripples, unlike that, if we apply a small perturbation, we will have a good precision but a very long response time.

Sliding mode MPPT. Sliding mode control is a nonlinear control type. It was originally introduced for the control of Variable Structure Systems (VSS).

In the control of the VSSs with sliding mode, the state trajectory is brought to a surface and then, by the switching law, it is obliged to remain in the vicinity of this sliding surface.
The sliding mode controller is based on the assumption of zero hysteresis on the sliding surface $S(x, t)=0$, and thus on a variable switching frequency.

The idea is to divide the state space by a decision boundary called «sliding surface».

Stabilization on the sliding surface is achieved by switching at each crossing of the decision boundary [11-13]. When PV panel is operating in its maximum power, we can write

$$
\begin{gathered}
\frac{\partial P_{P V}}{\partial V_{P V}}=0 ; \\
\frac{\partial P_{P V}}{\partial V_{P V}}=\left(\frac{\partial\left(V_{P V} \cdot I_{p v}\right)}{\partial V_{P V}}\right)=\left[\left(\frac{\partial I_{P V}}{\partial V_{P V}}\right) \cdot V_{P V}+I_{P V}\right] ; \\
\frac{\partial P_{P V}}{\partial V_{P V}}=\frac{\partial I_{P V}}{\partial V_{P V}} \cdot V_{P V}+I_{P V} .
\end{gathered}
$$

The switching surface adopted is the derivative of the power with respect to the voltage, and from equation (11) the sliding surface can be obtained by the following relation:

$$
S=\frac{\partial P_{P V}}{\partial V_{P V}}=\frac{\partial I_{P V}}{\partial V_{P V}} \cdot V_{P V}+I_{P V} .
$$

The switch control can be selected as:

$$
u= \begin{cases}0, & S>0 \\ 1, & S<0 .\end{cases}
$$

There are two operating zones separated by the MPP $(S(x)=0)$ as shown in Fig. 7, zone 1 for which the slope is positive $(S(x)>0)$, and zone 2 for which the slope is negative $(S(x)<0)$.

We can write also [14]:

$$
u=\frac{1}{2}(1-\operatorname{sign}(S)) .
$$

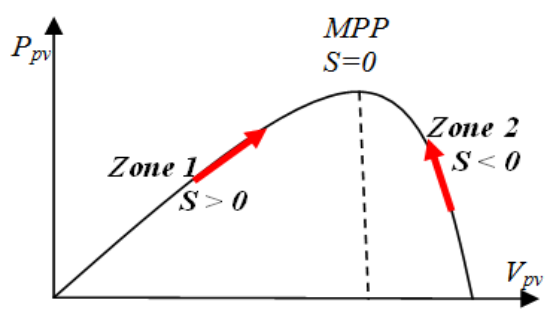

Fig. 7. Operating zones of PV system

Simulation of sliding mode MPPT. For the same conditions applied with $\mathrm{P} \& \mathrm{O}$ we obtain the following results. In Fig. 8-10 we observe amelioration of performances, with a ripple and disturbance less than the P\&O technique.

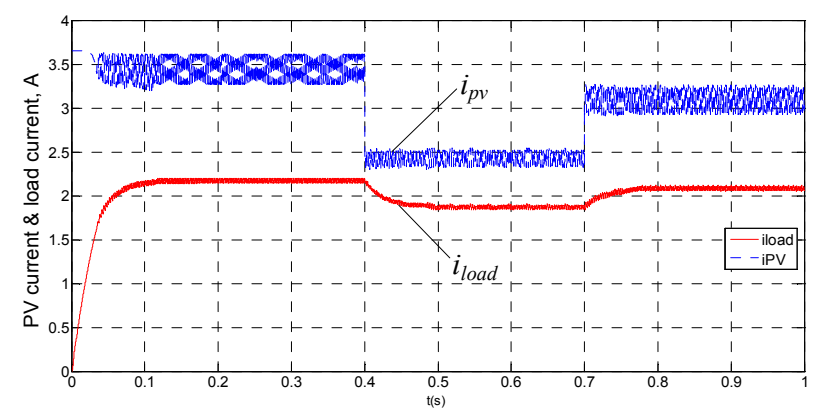

Fig. 8. Load and PV panel current for sliding mode MPPT 


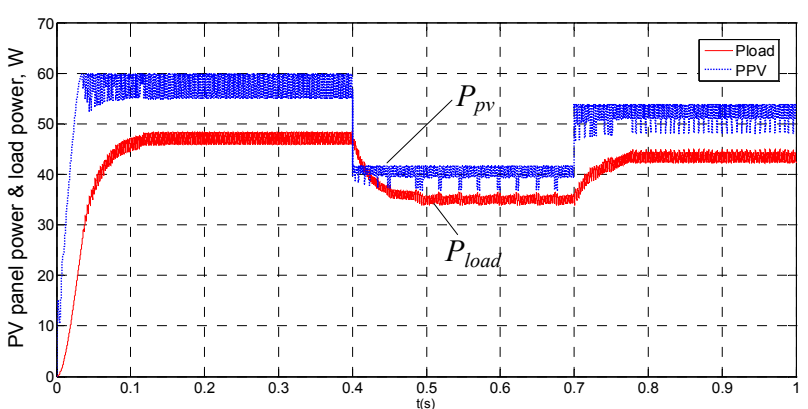

Fig. 9. Load and PV panel power for sliding mode MPPT

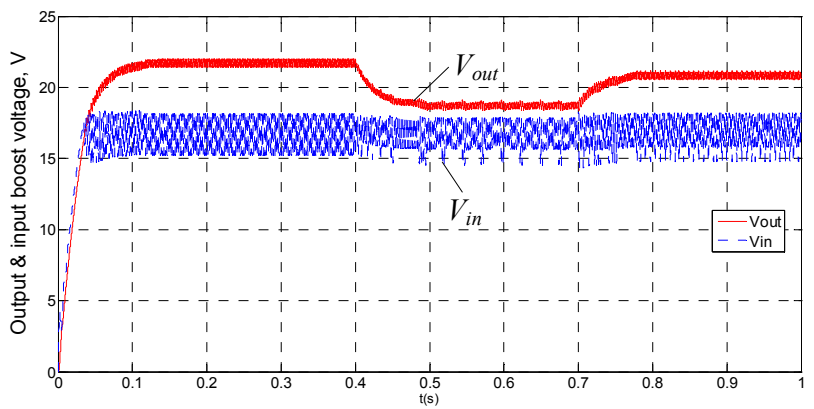

Fig. 10. Load and PV panel voltage for sliding mode MPPT

Ameliorate sliding mode MPPT. In sliding mode technique, the study is focused on the derivation of the power with respect to the voltage, thus it is appeared two zones depends on the sign of the sliding surface.

The ameliorate sliding mode is based on $\mathrm{P} \& \mathrm{O}$ principle, each switching control take into consideration the direction of the power variation $(\Delta P)$, and also the direction of the voltage variation $(\Delta V)$.

We can define four cases as shown in Fig. 11:

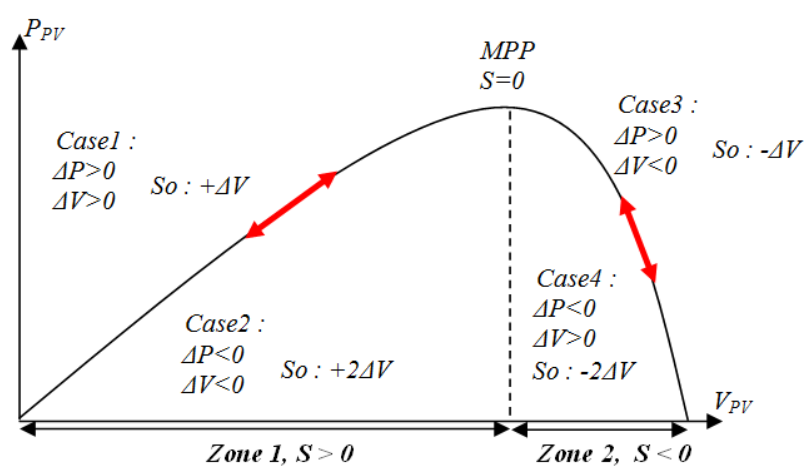

Fig. 11. The four situations of the operation point

Zone 1, case 1:

When operating point moves in zone 1 , from point $(k-1)$ to $(k)$ we notice that it approaches more the MPP, then, it should continue in the same direction.

Zone 1, case 2:

$$
V_{P V}(k+1)=V_{P V}(k)+\Delta V .
$$

When operating point always moves in zone 1, from the point $(k-1)$ to $(k)$, we note that it moves away from the MPP. In this case, it must change direction; we apply a positive double step (disturbance)

$$
V_{P V}(k+1)=V_{P V}(k)+2 \Delta V .
$$

Zone 2, case 3:

When the operating point moves in zone 2 , from the point $(k-1)$ to $(k)$, we notice that it is closer to the MPP, so that it will continue in the same direction

$$
V_{P V}(k+1)=V_{P V}(k)-\Delta V .
$$

Zone 2, case 4:

When operating point always moves in zone 2 , from the point $(k-1)$ to $(k)$, we note that it moves away from the MPP, then, in this case we must change the direction; we apply a negative double step (disturbance)

$$
V_{P V}(k+1)=V_{P V}(k)-2 \Delta V \text {. }
$$

We conclude that the step of disturbance must be doubled when $\Delta P<0$

$$
P_{P V}(k)<P_{P V}(k-1),
$$

where $V_{P V}(k), P_{P V}(k)$ are, respectively, the voltage and the power of the PV panel, at the iteration $(k) ; \Delta V$ is the step of disturbance of the voltage; $\Delta P$ is the resulting power variation due to the voltage disturbance.

Simulation of ameliorate sliding mode MPPT. For the same conditions applied with $\mathrm{P} \& \mathrm{O}$ we obtain the following results (Fig. 12-14).

This technique is simple and easily realized, because it is based on classic P\&O MPPT. By using the ameliorate sliding mode, the clear optimization of the performances but it needs more calculation time because of the existence of four cases, which means more precision but more iterations.

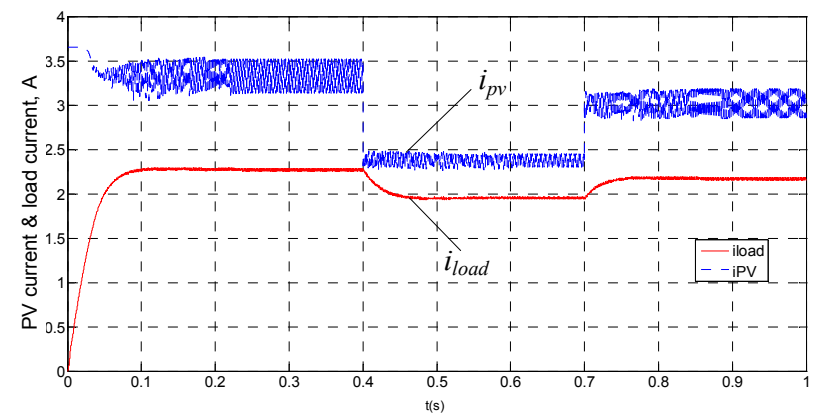

Fig. 12. Load and PV panel current for ameliorate sliding mode MPPT

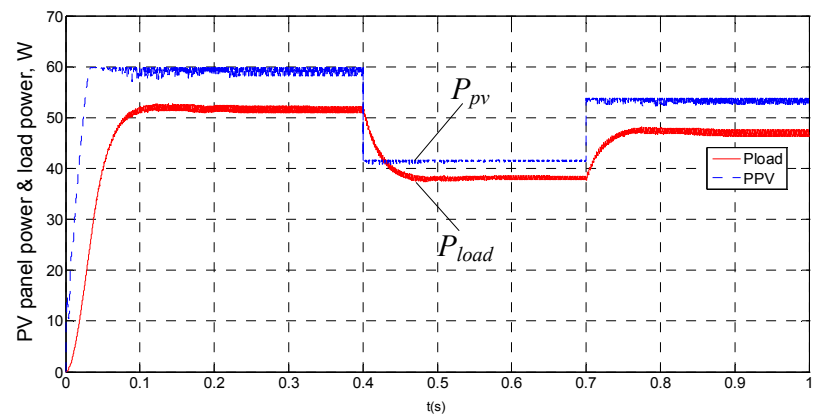

Fig. 13. Load and PV panel power for ameliorate sliding mode MPPT

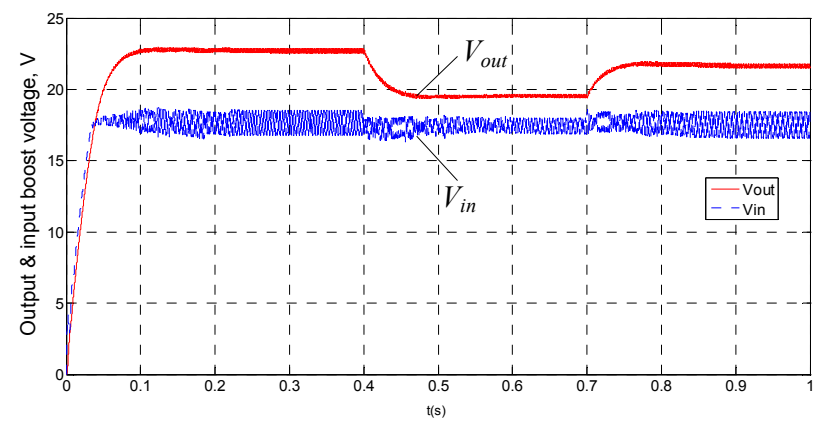

Fig. 14. Load and PV panel voltage for ameliorate sliding mode MPPT 
Fuzzy logic MPPT. The theory of fuzzy logic was developed in by Prof. Lotfi A. Zadeh. The text «Fuzzy Sets» appeared in 1965 in the review «Information and Control» [15].

The majority of the developed controllers use the simple diagram suggested by I. Mamdani for the singleinput/single-output system [16-18]. This diagram is shown in Fig. 15 (where SE, SCE - inputs gains; SdD output gain).

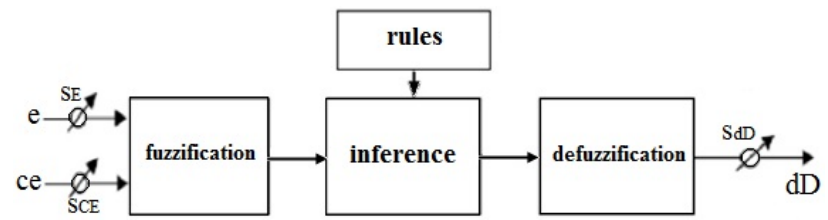

Fig. 15. General structure of a fuzzy controller

According to this diagram fuzzy system includes:

- the fuzzification corresponds to the process of determining the degree of member ship to each fuzzy partition;

- fuzzy rules (inference) indicate the use of the rules started by the various fuzzified input;

- defuzzification block corresponds to the transformation of outputs fuzzy values (linguistic form) to real values $(\Delta V)$.

These methods allow formulating a set of decisions in linguistic terms, using fuzzy sets to describe the error amplitudes, its variation and the appropriate control. By combining these rules, we can trace decision tables to give the values of controller output corresponding to situations of interest $[19,20]$.

The scale factors should be selected based on the study of the system such that, when the small transitory phenomenon, the permissible range for the error and its variation are not exceeded.

\section{Description of the fuzzy system.}

Error E. The error $E$ is defined as the error between $d P / d V$ and the seeking values $d P / d V=0$. The latter value corresponds to the unique extreme value of the curve $P(V)$. This extreme point is a maximum. More $E$ is positive; more the value of $P$ increase .Conversely, more $E$ is negative, more the value of $P$ decreases. Finally when $E$ tends to 0 , the value of $P$ tends towards its maximum, the MPP.

Variation of the error $\Delta \boldsymbol{E}$. The change in the error $\Delta E$ indicates in which direction and in what proportion the error changes in proportion as the algorithm is running. So when $\Delta E$ tends to 0 , the system stabilizes (but not necessarily MPP).

Output criteria (disturbance). The disturbance or increment corresponds to the adjustment value added to the voltage in each iteration of the algorithm. The fuzzy rules allow determining and connecting the output of the controller to input signals by linguistic terms taking into account the experience acquired by a human operator.

Rules table. After having done some tests by varying the number of output classes and rules allocation, we get the following rules table [10] (Table 1).

Table 1

\begin{tabular}{|c|c|c|c|c|c|c|c|}
\hline$\Delta E$ & NG & NM & NP & Z & PP & PM & PG \\
\hline NG & NG & NG & NG & NG & NM & NP & Z \\
\hline NM & NG & NG & NG & NM & NP & Z & PP \\
\hline NP & NG & NG & NM & NP & $Z$ & PP & PM \\
\hline$Z$ & NG & NM & NP & Z & PP & PM & PG \\
\hline PP & NM & NP & Z & PP & PM & PG & PG \\
\hline PM & NP & Z & PP & PM & PG & PG & PG \\
\hline PG & Z & PP & PM & PG & PG & PG & PG \\
\hline
\end{tabular}

Simulation of fuzzy MPPT. For the same conditions applied with $\mathrm{P} \& \mathrm{O}$ we obtain the following results (Fig. 17-19).

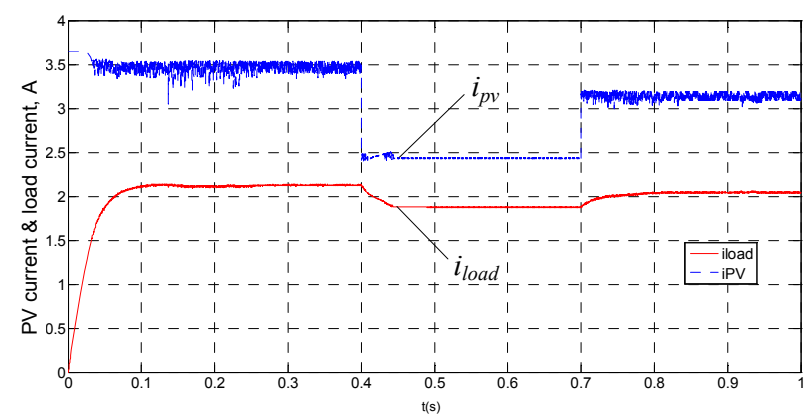

Fig. 17. Load current and PV current for fuzzy MPPT

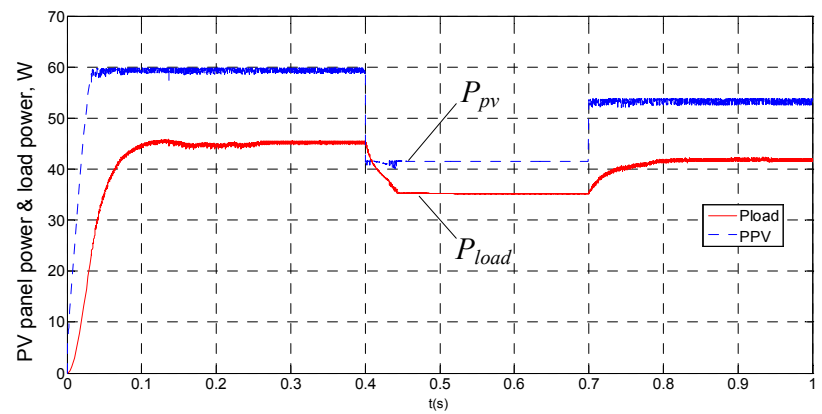

Fig. 18. Load power and PV power for fuzzy MPPT

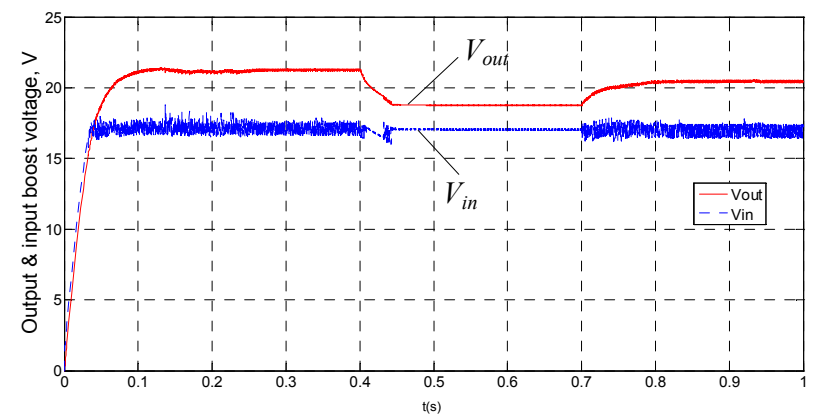

Fig. 19. Load voltage and PV voltage for fuzzy MPPT

We observe the amelioration in the evolutions of the various curves comparing to the classic P\&O MPPT and also comparing to the other techniques. Very low fluctuation in voltage, in power or in current evolution, this confirms the effectiveness and the superiority of the fuzzy system applied.

The advantage of this technique is that the step of disturbance is adapted by the fuzzy system according to the variation of inputs, thus a transient period is shorter 
without any overshooting compared to sliding mode MPPT and the ameliorated sliding mode MPPT.

\section{Conclusions.}

In order to supply an isolated site using photovoltaic system, it is very easy to connect directly the load to the supplying system. In this situation the photovoltaic panels are often oversized to ensure a sufficient power to provide the load; this led to an excessively expensive system.

The operation point system is obtained by the intersection between the curve of current depending to the voltage and the load curve.

It is necessary to integrate a power point tracking system, which has a role of detecting this point, and forces the system to works precisely on it via an electrostatic converter. For this aim a boost converter is used; its role is the adaptation of the supplying power and the augmentation of the output voltage.

As a comparative study, the converter is controlled by two techniques, sliding mode and fuzzy maximum power point tracking.

In the first part a classic perturb and observe method is treated and simulated in order to validate the studied model.

In sliding-mode method we define the sliding surface which is based on a hysteresis method, using the slope of the derivative of the power with respect to the voltage in order to reach the maximum power point. This method presents the advantage that it is independent on the system parameters. The simulation result shows the remarkable amelioration compared to the classic perturb and observe. The oscillations on the power response are the major disadvantage of this method.

The tracking behavior shows that Fuzzy maximum power point tracking system successfully and perfectly tracked the maximum power point with better performance than sliding-mode technique.

This controller guarantees high dynamic system performances, and eliminate the ripples in the power, the current and the voltage responses.

Conflict of interests. The authors declare no conflicts of interest.

\section{REFERENCES}

1. Weidong Xiao, Dunford W.G. A modified adaptive hill climbing MPPT method for photovoltaic power systems. 2004 IEEE 35th Annual Power Electronics Specialists Conference (IEEE Cat. No.04CH37551), Aachen, Germany, 2004, vol. 3, pp. 1957-1963. doi: https://doi.org/10.1109/pesc.2004.1355417.

2. Ben Salah C., Ouali M. Comparison of fuzzy logic and neural network in maximum power point tracker for PV systems. Electric Power Systems Research, 2011, vol. 81, no. 1, pp. 43-50. doi: https://doi.org/10.1016/j.epsr.2010.07.005.

3. Guldemir H. Sliding Mode Control of Dc-Dc Boost Converter. Journal of Applied Sciences, 2005, vol. 5, no. 3, pp. 588-592. doi: https://doi.org/10.3923/jas.2005.588.592.

4. Komurcugil H. Adaptive terminal sliding-mode control strategy for DC-DC buck converters. ISA Transactions, 2012, vol. 51, no. 6, pp. 673-681. doi: https://doi.org/10.1016/j.isatra.2012.07.005.

5. Bianconi E., Calvente J., Giral R., Mamarelis E., Petrone G., Ramos-Paja C.A., Spagnuolo G., Vitelli M. Perturb and Observe MPPT algorithm with a current controller based on the sliding mode. International Journal of Electrical Power \& Energy Systems, 2013, vol. 44, no. 1, pp. 346-356. doi: https://doi.org/10.1016/j.ijepes.2012.07.046.

6. Chu C.-C., Chen C.-L. Robust maximum power point tracking method for photovoltaic cells: A sliding mode control approach. Solar Energy, 2009, vol. 83, no. 8, pp. 1370-1378. doi: https://doi.org/10.1016/j.solener.2009.03.005.

7. Meekhun D., Boitier V., Dilhac J., Blin G. An automated and economic system for measuring of the current-voltage characteristics of photovoltaic cells and modules. 2008 IEEE International Conference on Sustainable Energy Technologies, Singapore, 2008, pp. 144-148. doi: https://doi.org/10.1109/icset.2008.4746989.

8. Sholapur S., Mohan K.R., Narsimhegowda T.R. Boost Converter Topology for PV System with Perturb And Observe MPPT Algorithm. IOSR Journal of Electrical and Electronics Engineering, 2014, vol. 9, no. 4, pp. 50-56. doi: https://doi.org/10.9790/1676-09425056.

9. Youssef E.B., Stephane P., Bruno E., Corinne A. New P\&O MPPT algorithm for FPGA implementation. IECON 2010 - 36th Annual Conference on IEEE Industrial Electronics Society, Glendale, AZ, 2010, pp. 2868-2873. doi: https://doi.org/10.1109/iecon.2010.5675079.

10. Nebti K., Debbabi F. Amelioration of MPPT P\&O Using Fuzzy-Logic Technique for PV Pumping. Renewable Energy for Smart and Sustainable Cities. ICAIRES 2018. Lecture Notes in Networks and Systems, 2019, vol. 62. Springer, Cham. doi: https://doi.org/10.1007/978-3-030-04789-4_43.

11. Ghazanfari J., Farsangi M.M. Maximum power point tracking using sliding mode control for photovoltaic array. Iranian Journal of Electrical and Electronic Engineering, 2013, vol. 9, no. 3, pp. 189-196. Available at: http://ijeee.iust.ac.ir/article-1-523-en.pdf. (accessed on 20 May 2020).

12. Chatrenour N., Razmi H., Doagou-Mojarrad H. Improved double integral sliding mode MPPT controller based parameter estimation for a stand-alone photovoltaic system. Energy Conversion and Management, 2017, vol. 139, pp. 97-109. doi: https://doi.org/10.1016/j.enconman.2017.02.055.

13. Vázquez N., Azaf Y., Cervantes I., Vázquez E., Hernández C. Maximum power point tracking based on sliding mode control. International Journal of Photoenergy, 2015, vol. 2015, pp. 1-8. doi: https://doi.org/10.1155/2015/380684.

14. Farhat M., Barambones O., Ramos J.A., Gonzalez de Durana J.M. Maximum power point tracking controller based on sliding mode approach. Conference Actas de las XXXV Jornadas de Automática, 3-5 September, 2014, Valencia. Available at: http://www.ja2014.upv.es/wp-

content/uploads/papers/paper 7.pdf (accessed on 15 June 2020).

15. Wu X., Shen J., Li Y., Lee K.Y. Fuzzy modeling and stable model predictive tracking control of large-scale power plants. Journal of Process Control, 2014, vol. 24, no. 10, pp. 16091626. doi: https://doi.org/10.1016/j.jprocont.2014.08.007.

16. Lacrose V., Titli A. Fusion and hierarchy can help fuzzy logic controller designers. Proceedings of the Sixth IEEE International Conference on Fuzzy Systems, Barcelona, Spain, 1997. doi: https://doi.org/10.1109/fuzzy.1997.616335.

17. Chouder A, Guijoan F, Silvestre S. Simulation of fuzzy-based MPP tracker and performance comparison with perturb \& observe method. Revue des Energies Renouvelables. 2008, vol. 11, no. 4, pp. 
577-586. Available at: https://www.asjp.cerist.dz/en/article/119627 (accessed on 25 July 2020).

18. Azzouzi M. Comparison between MPPT P\&O and MPPT fuzzy controls in optimizing the photovoltaic generator. International Journal of Advanced Computer Science and Applications (IJACSA), 2012, vol. 3, no. 12, pp 57-62. doi: https://doi.org/10.14569/ijacsa.2012.031208.

19. Zhang C., Zhao D. MPPT with asymmetric fuzzy control for photovoltaic system. 2009 4th IEEE Conference on Industrial Electronics and Applications, Xi'an, 2009, pp. 2180-2183. doi: https://doi.org/10.1109/iciea.2009.5138584.

20. Noman A.M., Addoweesh K.E., Mashaly H.M. DSPACE Real-Time Implementation of MPPT-Based FLC Method. International Journal of Photoenergy, 2013, vol. 2013, pp. 1-11. doi: https://doi.org/10.1155/2013/549273.

Received 08.11.2020

Accepted 11.12.2020

Published 25.02.2021
Khalil Nebti ${ }^{1}$, Doctor of Electrotechnical, Ryma Lebied ${ }^{2}$, Ph.D.,

${ }^{1}$ Electrical Engineering Laboratory of Constantine, LEC, Department of Electrical Engineering,

University of Constantine 1, 25000 Constantine, Algeria. e-mail: idor2003@yahoo.fr

2 Electrotechnical Laboratory Skikda (LES),

Department of Electrical Engineering, University 20 August 1955 ,

26 Road El Hadaiek 21000, Skikda, Algeria, e-mail: r.lebied@univ-skikda.dz

How to cite this article:

Nebti K., Lebied R. Fuzzy maximum power point tracking compared to sliding mode technique for photovoltaic systems based on DC-DC boost converter. Electrical Engineering \& Electromechanics, 2021, no. 1, pp. 67-73. doi: 10.20998/2074-272X.2021.1.10. 